\title{
乾燥収縮するコンクリート壁面の拘束度マップ MAPPING OF RESTRAINING RATIO FOR CONCRETE WALLS WITH DRYING SHRINKAGE
}

\author{
寺西浩司*, 中村雄一**
}

\author{
Kohii TERANISHI and Yuichi NAKAMURA
}

\begin{abstract}
In this study, the distribution of restraining ratio in concrete walls with various conditions was calculated by FEM analysis and a uniaxial model, and the map of restraining ratio for the control design of shrinkage cracking was created based on the results. The distribution of restraining ratio shown in the map has the following characteristics. (1) The areas whose restraining ratio can not be calculated by the uniaxial model (peculiar areas) occur at the upper and lower parts of both ends of a wall. (2) The position and largeness of peculiar area hardly changes depending on stiffness balance between members and number of layer and span. (3) The average restraining ratio at the peculiar area at the lower part of both ends is obtained by adding a constant value to the restraining ratio calculated by the uniaxial model.
\end{abstract}

Keywords : Drying shrinkage, Cracking, External restraining, FEM analysis, Uniaxial model 乾燥収縮，ひび割れ，外部拘束，FEM解析，1軸モデル

\section{1. はじめに}

鉄筋コンクリート建物の収縮ひび割れ制御対策を性能設計的な手 法に基づいて合理的に策定するためには、ひび割れ発生状況（ひび 割れの有無、および発生位置・長さ・幅など）の事前予測が欠かせ ない。しかし、その予測手法は現状では実質的にFEM解析しかなく、 これは、かなりの手間と専門的な能力を要するものであるため、ご く一般的な建物のひび割れ対策の実務的な検討手段には適さない。

一方、コンクリート部材に生じる自由収縮変形は、通常、収縮速 度や剛性の異なる周辺の部材に拘束されるため、その拘束の度合い を表す指標である拘束度も、ひび割れの発生状況に大きな影響を及 ぼす。したがって、ひび割れ予測にあたっては、使用するコンクリー トの自由収縮ひずみのほかに、コンクリート部材の拘束度を把握し ておくことが重要となる。

以上のことを踏まえると、FEM解析より簡便で実用的なひび割れ発 生状況の予測手法として、拘束度分布を諸条件ごとにパターン化し た汎用的な設計資料を予め整備しておき、それを活用してひび割れ 予測を行うという方法が考えられる。ただし、拘束度の值は、部材 間で異なるのみならず、一つの部材内でも、様々な要因によって複 雑に分布する。また、拘束度に関しては、これまでに、中西1)、鈴
木ら 2)、尹ら ${ }^{3)} に よ り$ 解析的な研究が報告されているものの、これら は、限定的な条件下での拘束度の計算結果であり、ひび割れ制御設 計資料として有効に活用できるようにはなっていない。

このような背景から、筆者らは、これまでに、拘束度分布を体系 的に整理した収縮ひび割れ制御設計資料の作成を最終的な目的とし て、乾燥収縮するコンクリート壁面における拘束度分布の規則性を 見出すための実験的・解析的検討を行ってきた。そして、拘束度 を、図1に模式図を示すような、次の $2 つ$ 領域に工学的に区分して 考えることが合理的であるとの知見を得た 4 )。

(1)端部以外：曲げ変形が卓越し、平面保持の仮定が成立することか ら、拘束方向（すなわち、最大主応力方向）が水平で、拘束度の 高さ方向の分布が直線的となる領域。なお、この領域では、コン クリート壁面を5章に後述する1軸モデルに置き換えることにより 拘束度分布を計算できる。

(2)端部：せん断変形が卓越し、平面保持の仮定が成立せず、拘束方 向が乱れて拘束度の高さ方向の分布が非直線的となる領域。

なお、このことは、コンクリート壁面の拘束度分布を次の方針に より予測できる可能性があることを意味している。すなわち、(1)ま ず、コンクリート壁面の拘束度分布を 1 軸モデルにより計算する、(2)

\footnotetext{
* 名城大学理工学部建築学科 教授・博士 (工学)

** 矢作建設工業(侏建築事業本部施工本部 副主任 ·修士 (工学)

Prof., Dept. of Architecture, Faculty of Science and Technology, Meijo Univ., Dr.Eng.

Building Division, Yahagi Construction Co., Ltd., M.Eng.
} 
次に、予め用意された設計資料を活用し、コンクリート壁面に関寸 る諸条件を考慮して、上記 (1)による計算值が適用できない領域（す なわち、端部）の位置や、その領域における拘束度の值などを把握 する。

本研究では、既報4)に続く一連の研究の第2段階として、上記の主 旨に沿った設計資料としてのコンクリート壁面の拘束度マップを作 成した。すなわち、条件を様々に変化させたコンクリート壁面にお ける拘束度分布をFEM解析により計算し、それらの結果を整理して、 1軸モデルによる拘束度の計算值が適用できない領域（1軸モデルの 計算値より拘束度が大きくて、収縮ひび割れが発生しや寸い領域) をマッピングした。また、その領域における拘束度の值および拘束 方向を表示した。

\section{2. 拘束度の定義および本研究で想定するひび割れ予測の手順}

拘束度は、次式のように、拘束ひずみ（応力に換算されるひずみ） $\varepsilon_{f}-\varepsilon_{c}$ と自由収縮ひずみ $\varepsilon_{f}$ の比により定義される ${ }^{5)} 。$

$$
\lambda=\frac{\varepsilon_{f}-\varepsilon_{c}}{\varepsilon_{f}}
$$

ここに、 $\lambda$ : 拘束度（拘束なし：0、完全拘束 $: 1 ） 、 \varepsilon_{f}$ : 自由収縮 ひずみ、 $\varepsilon_{c}:$ 全ひずみ（測定ひずみ）。

また、本研究では、既報4) と同様に、ひび割れの発生状況を、日 本建築学会「鉄筋コンクリート造建築物の収縮ひび割れ制御設計・ 施工指針（案） - 同解説」5)の「3章 性能規定」に示された手順に より予測することを想定している。したがって、収縮ひび割れ発生 強度（割裂引張強度に、ひび割れ発生低減係数として通常 0.7 程度を 乗じた值）と次式により求めた収縮拘束応力の比較により、ひび割 れ発生の有無を判断することがその基本となる。

$$
\sigma=\frac{E}{1+\phi} \lambda \varepsilon_{f}
$$

ここに、 $\sigma$ : 収縮拘束応力 $\left(\mathrm{N} / \mathrm{mm}^{2}\right) 、 \phi:$ クリープ係数、 $E$ : ヤ ング係数 $\left(\mathrm{N} / \mathrm{mm}^{2}\right)$ 。

\section{3. 解析概要}

\section{1 解析ケース}

表1に解析要因とその水準を示す。本研究では、基礎を含む建物の 1面の壁全体を解析対象とし、壁面の形状を表す $L / H$ （壁面の幅/高 さ）、「基礎の水平方向の軸剛性/地上部分の梁の水平方向の軸剛性 の合計」（以下、剛性比という）、および層数・スパン数を変化さ せて解析を行った。

\begin{tabular}{c|c}
\hline 要因 & 水準 \\
\hline$L / H$ & $0.5,1,2,4,8$ \\
\hline 剛性比 & $0.25,0.5,1,2$ \\
\hline \multirow{3}{*}{ 層数・スパン数 } & 1層1スパン $(1 \mathrm{~F} 1 \mathrm{~S})$, \\
& 3層4スパン (3F S $),$ \\
& 6層8スパン (6F8S) \\
\hline
\end{tabular}

表2 解析ケース

\begin{tabular}{c|c|c|c|c}
\hline \multirow{2}{*}{$\begin{array}{l}\text { 層数・ } \\
\text { スパン数 }\end{array}$} & \multicolumn{5}{|c}{ 剛性比 } \\
\hline $1 \mathrm{~F} 1 \mathrm{~S}$ & & 0 & & \\
\hline $3 \mathrm{~F} 4 \mathrm{~S}$ & & 0 & 0 & $\bigcirc$ \\
\hline $6 \mathrm{~F} 8 \mathrm{~S}$ & & 0 & & \\
\hline
\end{tabular}

表1 解析要因とその水準

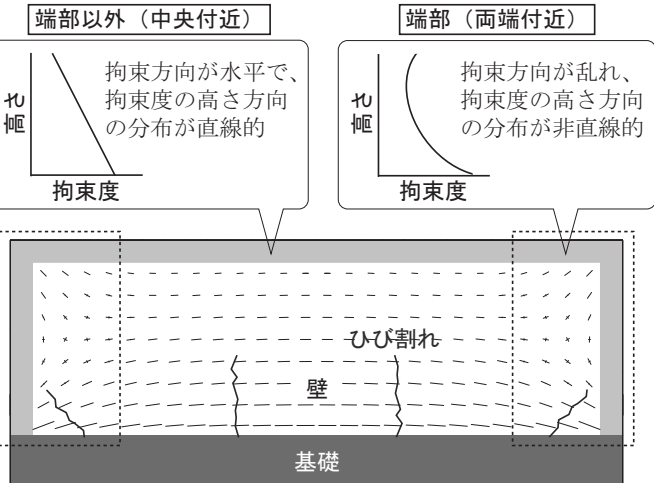

※図中の直線は、拘束方向および拘束度の大きさを表す。 図1 コンクリート壁面の拘束度分布

表2に解析ケースを示す。表中に○印を示したケースについて $L / H$ を0.5、1、2、4および8の5水準に変化させた。

\section{2 解析方法}

コンクリート壁面にひび割れが初めて発生する時点での拘束度分 布の把握を目的として、ひび割れの発生は考慮せず、3次元FEM解析 プログラム ${ }^{6)}$ を用いて逐次弾性解析を行った。使用したプログラム は、ヤング係数、ポアソン比、自由収縮ひずみなどの材料特性值を 入力值とし、剛性の異なる部材の変形や内部応力・ひずみを計算す るものである。本研究では、解析で得られた各要素の最大主ひずみ （全ひずみ）から式(1)により拘束度を計算した。

\section{3 解析モデル}

図 2 に要素分割図の一例を示す。本解析では、平面応力状態を仮定 し、壁面の片側半分を疑似的な2次元モデルに置き換えた。また、解 析モデルの寸法は拘束度などの解析結果に影響を及ぼさないことか ら 7)、解析モデルの高さは、すべてのケースで $1,100 \mathrm{~mm}$ (地上部分 $1,000 \mathrm{~mm}+$ 基礎部分 $100 \mathrm{~mm}$ ）一定とし、幅は、 $L / H$ の水準に応じて変 化させた。

解析モデルは、壁（無筋コンクリート）、梁・柱（鉄筋コンクリー 卜）および基礎の要素で構成されたものとした。また、モデル化に あたっては、全てのケースで要素分割数を同一としたうえで、水平・ 垂直方向ともに均等間隔にメッシュ分割し（ただし、中心列の要素 の幅は例外的に他の要素の $1 / 2$ とした）、その分割したソリッド要素 に対して、ケースに応じて各部材の要素を割り付けた。その際、層 数・スパン数の変化に対応しやすいモデルとするために、梁および 柱は1段または1列の要素とし、梁および柱要素は、配筋方向の剛性 を鉄筋比（1.5\%）に応じて増大させる形でモデル化した。

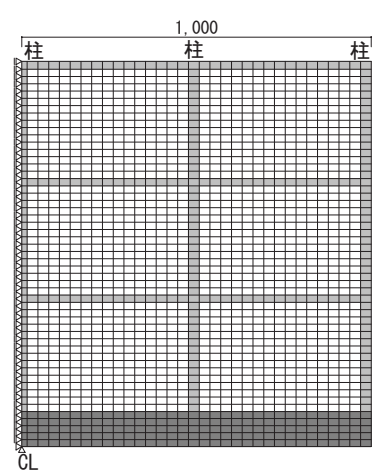

(a) $3 \mathrm{~F} 4 \mathrm{~S} \cdot \mathrm{L} / \mathrm{H}=2$

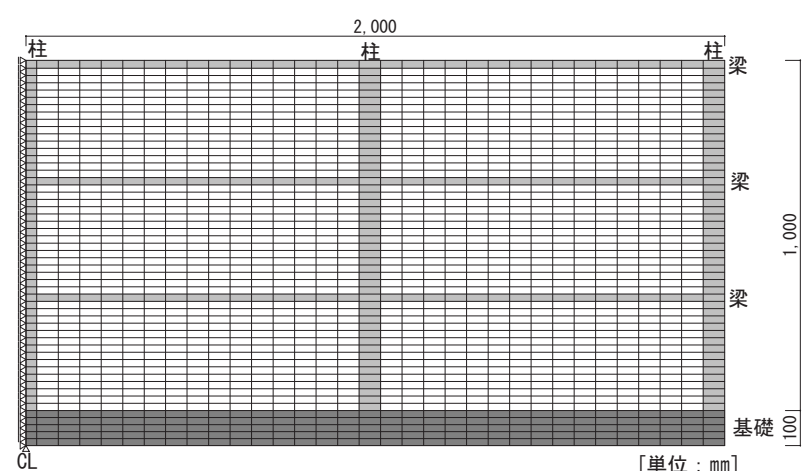

(b) $3 \mathrm{~F} 4 \mathrm{~S} \cdot \mathrm{L} / \mathrm{H}=4$
図2 解析モデル 
なお、解析モデルの奥行きは部材にかかわらず一律 $(20 \mathrm{~mm})$ とし、 梁要素では、梁せいが階高の $20 \%$ 、奥行きが壁部分の 2.5 倍であると 仮定したうえで、その断面と剛性が等価になるようにヤング係数を 調整した。また、解析条件を単純化するため、梁と柱の剛性が等し くなるように柱要素のヤング係数を定めた。基礎に関しては、水平 方向の軸剛性が表1中に示した剛性比の水準から計算される值となる ように、ヤング係数を定めた。

\section{4 境界条件}

図2に示したように、解析モデルのCL位置では、節点の水平方向を 固定した。また、その下端では節点の垂直方向も固定した。

\section{5 材料特性値}

表 3 に材料特性值を示す。コンクリートのヤング係数、圧縮強度お よび乾燥収縮ひずみの時間関数には、土木学会「コンクリート標準 示方書 [設計編］」8)に示されている式を用いた。その際、コンク リートの自由収縮ひずみ（乾燥収縮ひずみ）は、材齢5日（型枠の取 外し時期を想定）以降から発生するものとし、壁コンクリートの時 間関数は、187日（乾燥期間182日）の時点で自由収縮ひずみが $1000 \times 10^{-6}$ となるように設定した。また、梁・柱コンクリートの時 間関数は、部材の厚みが壁よりも厚いことを考慮して定めた。図3に、 これらの乾燥収縮ひずみの時間関数を図示する。なお、梁・柱要素 は、配筋方向に対して、コンクリートの自由収縮ひずみが鉄筋によ り拘束された結果として生じる全ひずみの分だけ、部材として自由 収縮するものとした。

また、クリープは、通常、コンクリート部材の収縮変形に対して 大きな影響を与える。しかしながら、本研究の解析対象の場合、拘 束体と非拘束体のいずれにもクリープが生じ、その収縮変形に対す る影響は相殺される傾向にあると考えられる。また、既報4 におけ る検討では、壁面の拘束度分布を調べるための実験の結果と、その 実験を対象とした、クリープをごく簡略的にしか考慮していない解
表3 材料特性値

\begin{tabular}{|c|c|c|c|c|}
\hline 特性值 & \multicolumn{2}{|c|}{ コンクリート } & 鉄筋 & 基礎 \\
\hline $\begin{array}{c}\text { ヤング係数 } \\
\left(\mathrm{kN} / \mathrm{mm}^{2}\right)\end{array}$ & $\begin{array}{l}\quad E(t)=4.7 \times f_{c}(t)^{0.5} \\
\text { ここに、 } \\
\qquad f_{c}(t)=\frac{t}{4.5+0.95 t}>\end{array}$ & 26.64 & 188 & $\begin{array}{l}\text { 剛性比の水準 } \\
\text { から計算され } \\
\text { る值 }\end{array}$ \\
\hline ポアソン比 & 0.2 & & 0.3 & 0.3 \\
\hline $\begin{array}{l}\text { 自由収縮 } \\
\text { ひずみ }\end{array}$ & $\begin{array}{r}\varepsilon_{f}(t)=1588 \times 10^{-6} \\
こ こ に 、 \begin{array}{c}\text { 壁 } \\
\text { 梁・柱 }: a\end{array}\end{array}$ & $\begin{array}{l}\quad \frac{t-5}{a+(t-5)} \\
=107.4, \\
=138.9\end{array}$ & - & - \\
\hline
\end{tabular}

$E(t):$ ヤング係数 $\left(\mathrm{kN} / \mathrm{mm}^{2}\right), t$ : 材齢 $($ 日 $)$,

$f_{c}(t)$ : 圧縮強度 $\left(\mathrm{N} / \mathrm{mm}^{2}\right), \varepsilon_{f}(t)$ : 自由収縮ひずみ

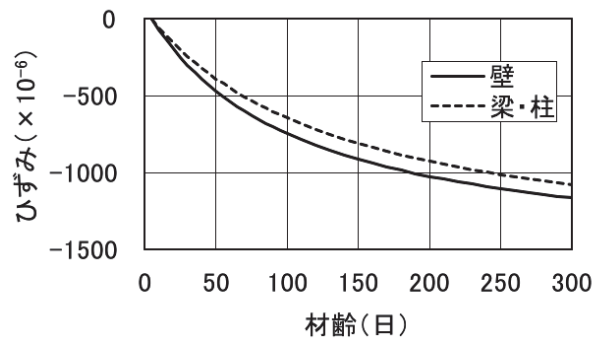

図3 コンクリートの乾燥収縮ひずみの時間曲線

析の結果とに大きな差異は生じなかった。これらのことから、本解 析では、コンクリートのクリープは考慮しなかった。

\section{4. 解析結果}

図4に、壁コンクリートの自由収縮ひずみが $800 \times 10^{-6}$ になった時 点における変形状況を、剛性比 0.5 の一部のケースについて示す。同 図から、壁面下部の水平方向の収縮変形が基礎により拘束されてい る様子がわかる。

図5に、図4と同一時期・同一ケースにおける拘束度分布を示す。

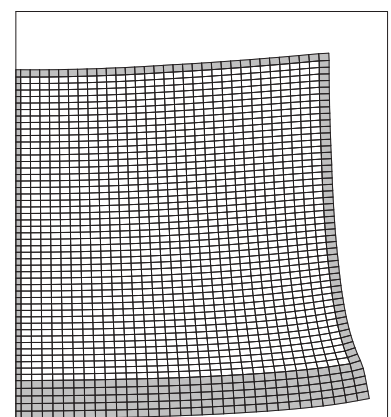

$\mathrm{CL}$

(a) $1 \mathrm{~F} 1 \mathrm{~S} \cdot \mathrm{L} / \mathrm{H}=2$

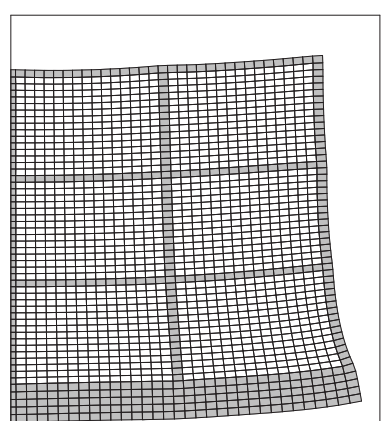

(b) $3 \mathrm{~F} 4 \mathrm{~S} \cdot \mathrm{L} / \mathrm{H}=2$

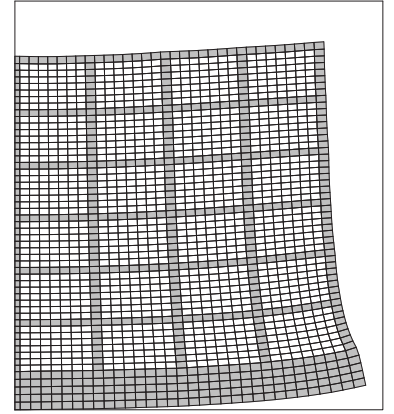

(c) $6 \mathrm{~F} 8 \mathrm{~S} \cdot \mathrm{L} / \mathrm{H}=2$

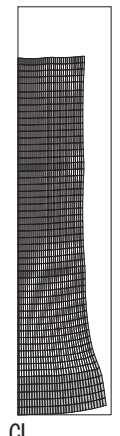

(d) $3 \mathrm{~F} 4 \mathrm{~S} \cdot \mathrm{L} / \mathrm{H}=0.5$

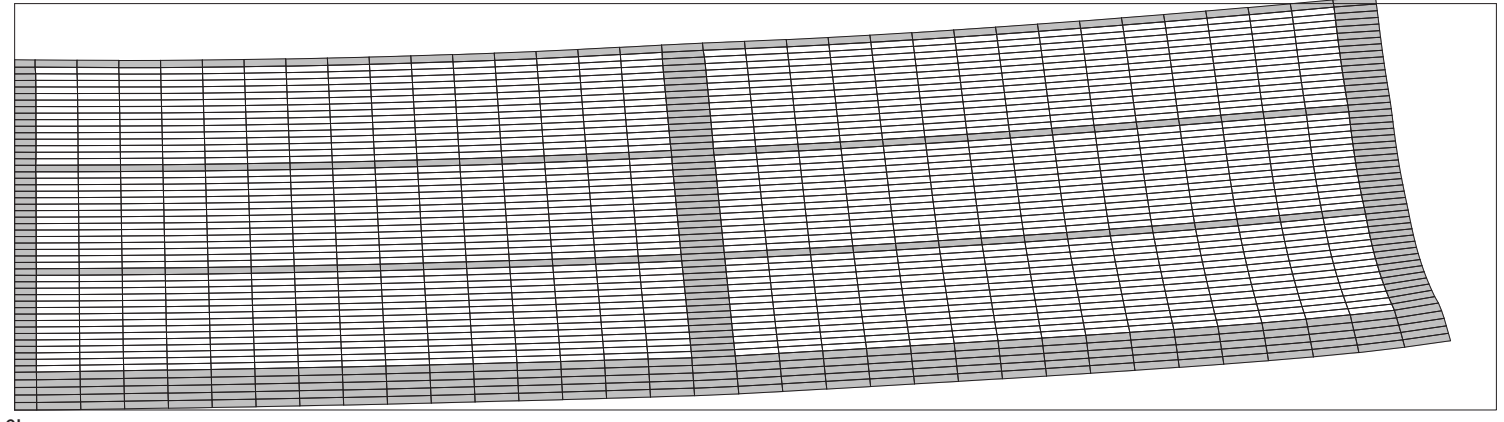

CL

(e) $3 \mathrm{~F} 4 \mathrm{~S} \cdot \mathrm{L} / \mathrm{H}=8$

図4 変形状況（剛性比0.5の一部のケース） 


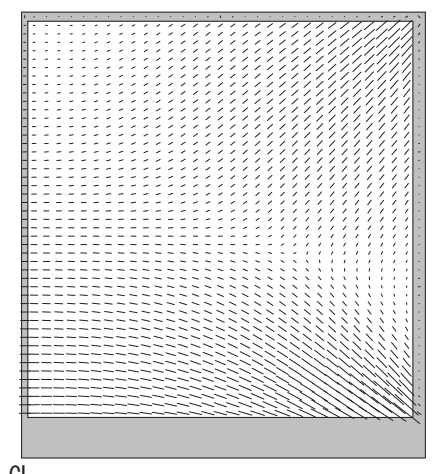

(a) $1 \mathrm{~F} 1 \mathrm{~S} \cdot \mathrm{L} / \mathrm{H}=2$

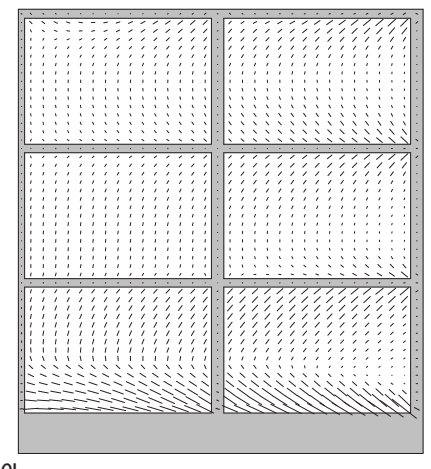

(d) $3 \mathrm{~F} 4 \mathrm{~S} \cdot \mathrm{L} / \mathrm{H}=0.5$

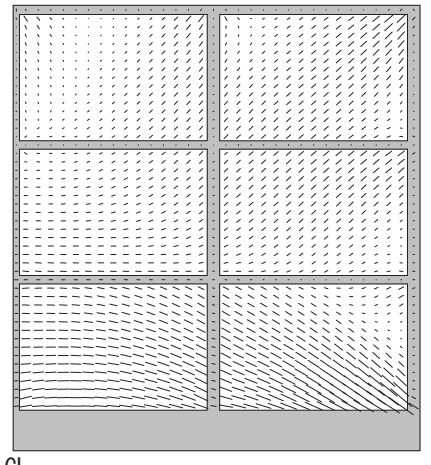

(b) $3 \mathrm{~F} 4 \mathrm{~S} \cdot \mathrm{L} / \mathrm{H}=2$

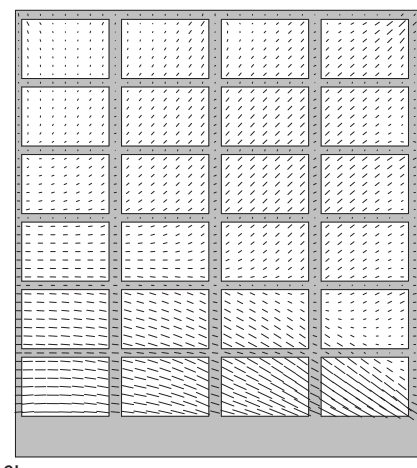

$\mathrm{CL}$

(c) $6 \mathrm{~F} 8 \mathrm{~S} \cdot \mathrm{L} / \mathrm{H}=2$

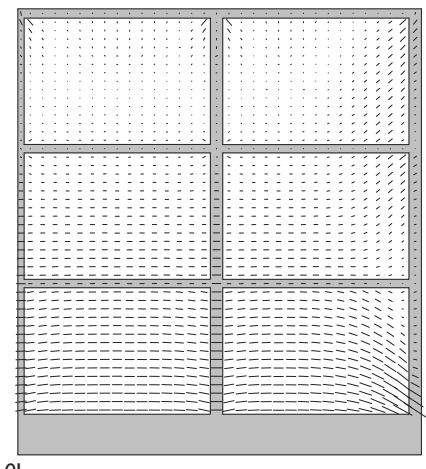

(e) $3 \mathrm{~F} 4 \mathrm{~S} \cdot \mathrm{L} / \mathrm{H}=8$

\section{図5 拘束度分布（剛性比0.5の一部のケース）}

ここで、同図は、全てのケースで、縦横の比が $L / H=2$ と同じになる ように壁面の形状を修正して表示してある。また、図中の直線の傾 きは、最大主ひずみ方向（すなわち、拘束方向）を表し、長さは拘 束度の大きさを表している（正の值のみを表示する）。同図から、 全てのケースにおいて、基礎による拘束の影響により壁面下部の拘 束度が大きくなっていることがわかる。また、壁面下端部（図中に おける右端の下部）では拘束度が極端に大きくなっている。さら に、 $L / H$ がある程度以上大きい場合、壁面の端部以外の領域では拘 束方向が水平に近いが、端部では拘束方向が乱れている様子が見て 取れる。なお、壁面の拘束度分布が以上のような様相となるのは、 既報4)で報告したように、壁面の端部以外の領域では、曲げ変形が 卓越し、平面保持の仮定が十分成立するのに対し、端部では、曲げ よりもせん断変形が卓越し、平面保持の仮定が成立しないことによ る。

\section{1軸モデルによる拘束度の計算}

筆者らは、既報4)において、壁面を1軸モデルに置き換えて、その 水平方向の拘束度を、Compensation Plane法9) (マスコンクリート の温度応力を計算する手法の一種）と同様の原理により計算する方 法を提案した。また、この方法により、壁面の端部以外の領域にお ける拘束度を計算可能であることを報告した。本研究では、各種要 因の変化に伴って、この計算方法により拘束度を計算できない領域 がどのように変化するのかを調べるために、FEM解析と同一のケース に対して、この計算方法を用いて（すなわち、後出の式(3)により） 水平方向のひずみ（全ひずみ）を計算し、さらに、式(1)により拘束 度を求めた。

図6 (a)に計算モデルを示す。このモデルは、建物の1面の壁全体を

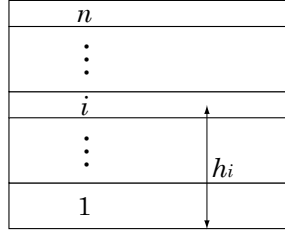

(a) 計算モデル

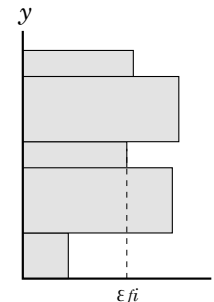

(b) 自由収縮ひずみ

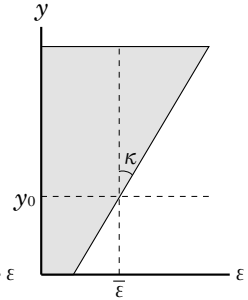

(c) 全ひずみ
図6 計算方法の概略

表4 記号（i番目の部材の形状・物性関係）

\begin{tabular}{c|l}
\hline 記号 & \multicolumn{1}{|c}{ 説 明 } \\
\hline$D_{i}$ & 部材のせい $(\mathrm{cm})$ \\
\hline$b_{i}$ & 部材の幅 $(\mathrm{cm})$ \\
\hline$A_{i}$ & 部材の断面積 $=b_{i} \times D_{i}\left(\mathrm{~cm}^{2}\right)$ \\
\hline$h_{i}$ & 部材中心の壁面モデル底面からの高さ $(\mathrm{cm})$ \\
\hline$I_{i}$ & 部材の断面2次モーメント $\left(\mathrm{cm}^{4}\right)$ \\
\hline$E_{i}$ & 部材のヤング係数 $\left(\mathrm{N} / \mathrm{cm}^{2}\right)$ \\
\hline$\varepsilon_{f i}$ & 部材の自由収縮ひずみ \\
\hline
\end{tabular}

基礎を含めてモデル化するものであり、高さ方向に積層された $n$ 個 の部材により構成される（各部材の断面は四角形であるとする）。 また、その構成部材としては、壁、梁および基礎（最下層）が想定 される。そして、自由収縮ひずみは、例えば図6 (b)に示すように、 各部材内部では均一に分布しているものとする。なお、表4に、下か ら $i$ 番目にある部材の形状および物性を表す記号を示す。また、本研 究で用いた1軸モデルによるひずみの計算式4)を以下に示す。

$$
\begin{gathered}
\varepsilon_{c}=\bar{\varepsilon}+\kappa\left(y-y_{0}\right) \\
\text { ここに、 } \\
\bar{\varepsilon}=\sum_{\mathrm{i}=1}^{n} \mathrm{~A}_{\mathrm{i}} \mathrm{E}_{\mathrm{fi}} / \sum_{\mathrm{i}=1}^{n} \mathrm{~A}_{\mathrm{i}} \mathrm{E}_{\mathrm{i}}
\end{gathered}
$$




$$
\begin{aligned}
& \kappa=\sum_{\mathrm{i}=1}^{\mathrm{n}} \mathrm{A} \mathrm{E}_{\mathrm{i}} \varepsilon_{\mathrm{fi}}\left(\mathrm{h}-\mathrm{y}_{0}\right) / \sum_{i=1}^{n} \mathrm{E}_{\mathrm{i}}\left\{\mathrm{I}_{\mathrm{i}}+\mathrm{A}\left(\mathrm{h}-\mathrm{y}_{0}\right)^{2}\right\} \\
& \mathrm{y}_{0}=\sum_{\mathrm{i}=1}^{\mathrm{n}} \mathrm{A} \mathrm{E}_{\mathrm{i}} \mathrm{h} / \sum_{\mathrm{i}=1}^{\mathrm{n}} \mathrm{A} \mathrm{E}_{\mathrm{i}}
\end{aligned}
$$

ここに、 $\varepsilon_{c}$ : 全ひずみ、 $\bar{\varepsilon}$ : 軸方向の平均ひずみ、 $\kappa$ : 曲率（1/ $\mathrm{cm}) 、 y_{0}$ : 壁面モデルの中立軸の底面からの高さ $(\mathrm{cm})$ 。

図7に、1軸モデルにより計算した拘束度（水平方向）の高さ方向 の分布を示す。1軸モデルでは、拘束度の高さ方向の分布は、壁面の どの水平方向の位置においても同一であり、また、壁面の幅（すな わち、 $L / H)$ には左右されないので、図中には、剛性比、層数・ス パン数ごとに計算結果を1本の線で示してある。
図7 (a) から、剛性比が大きいと、基礎による拘束が大きくなるこ とに起因して、壁面下部の拘束度が大きくなることがわかる。ま た、図 7 (b) から、層数・スパン数が変化しても、拘束度分布の計算 結果に大きな差異が生じないことがわかる。

図8は、 $L / H$ の大きいケースに着目し、1軸モデルによる計算およ びFEM解析によって得られた拘束度の高さ方向の分布を重ねて示した ものである (3F4S、剛性比0.5、 $L / H=8)$ 。ここで、解析結果につい ては、中央スパンの中心の列の值を示してある。また、解析值の分 布が直線的であるということは、平面保持を仮定した1軸モデルによ る拘束度の予測が可能な領域であることを意味している。図8から、 解析值は直線的に分布しており、また、計算值とほぼ一致している

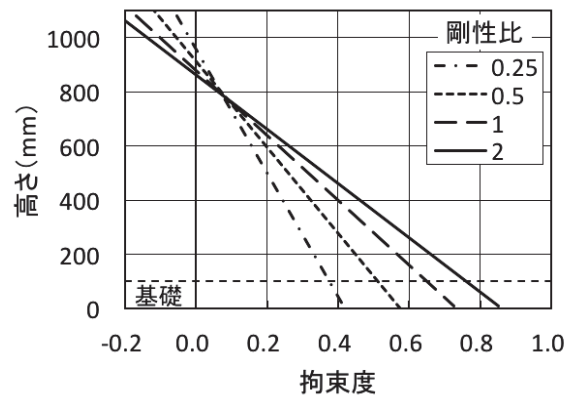

（a）剛性比の影響 (3F4S)

図7 1軸モデル

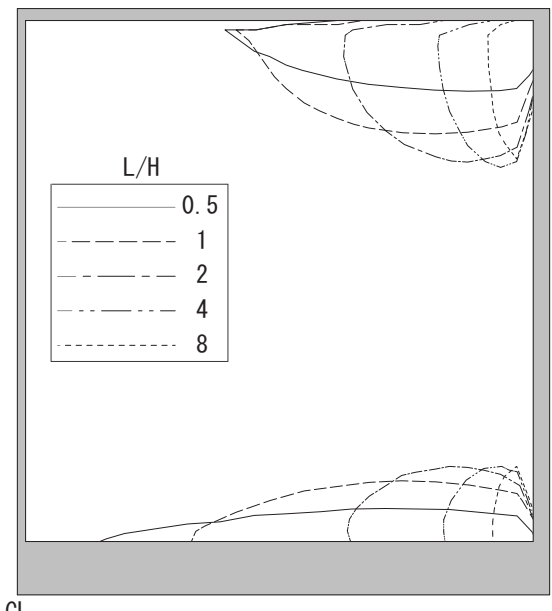

（a） $1 \mathrm{~F} 1 \mathrm{~S} \cdot$ 剛性比 0.5

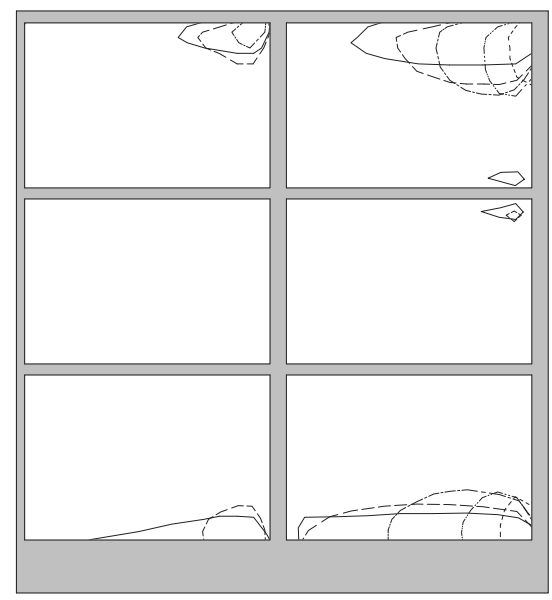

(d) 3F4S ・ 剛性比0.25

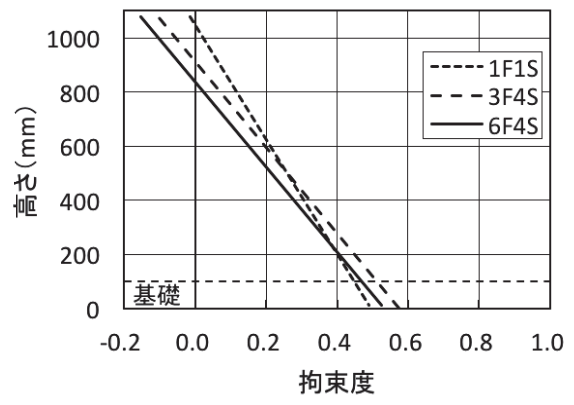

(b) 層数・スパン数の影響 (剛性比 0.5 )

平方向の拘束度の計算値

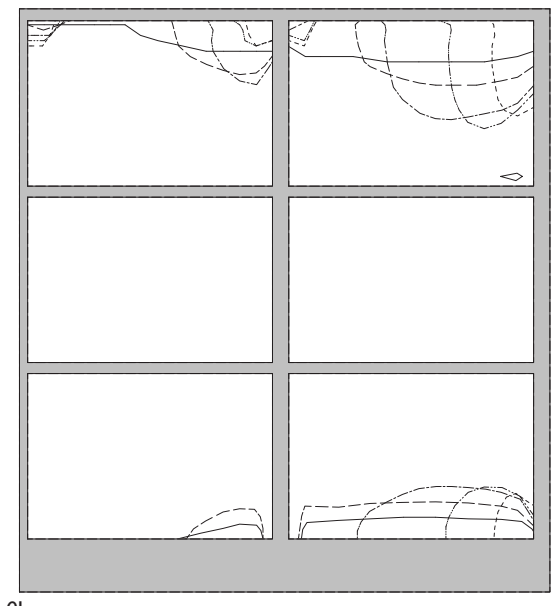

（b） $3 \mathrm{~F} 4 \mathrm{~S}$ ・ 剛性比 0.5

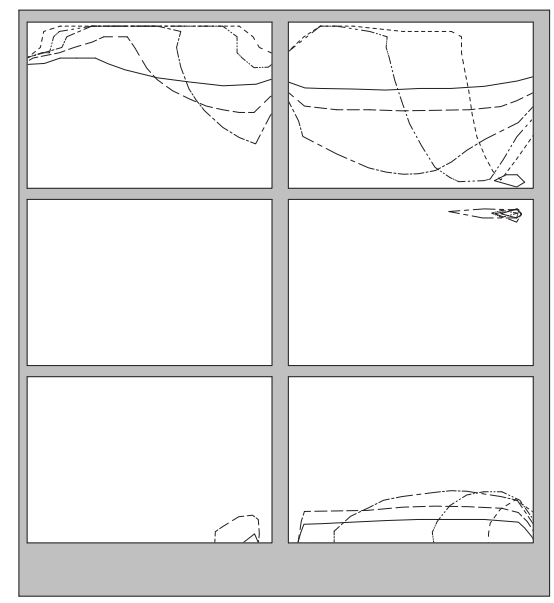

(e) $3 \mathrm{~F} 4 \mathrm{~S}$ ・ 剛性比 1.0

図9 特異領域（拘束度マップ）

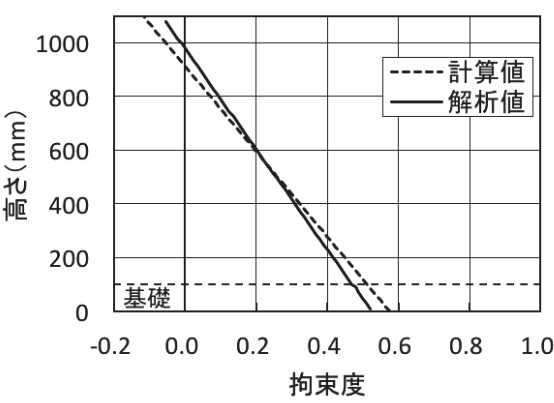

図8 水平方向の拘束度の高さ方向の分布 (3F4S · 剛性比0. $5 \cdot \mathrm{L} / \mathrm{H}=8$ )

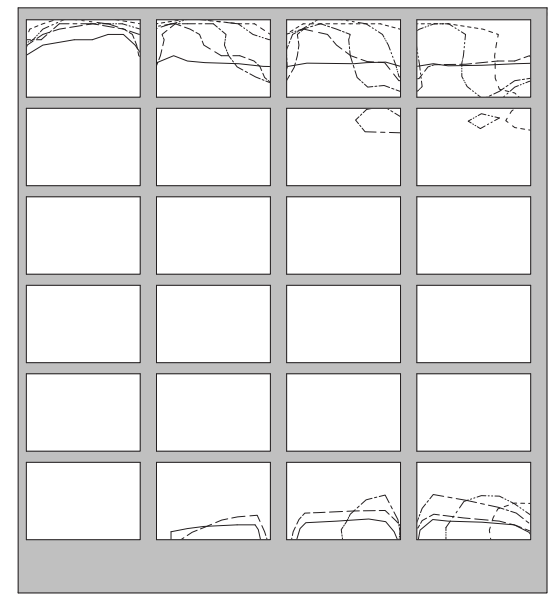

CL

(c) $6 \mathrm{~F} 8 \mathrm{~S} \cdot$ 剛性比 0.5

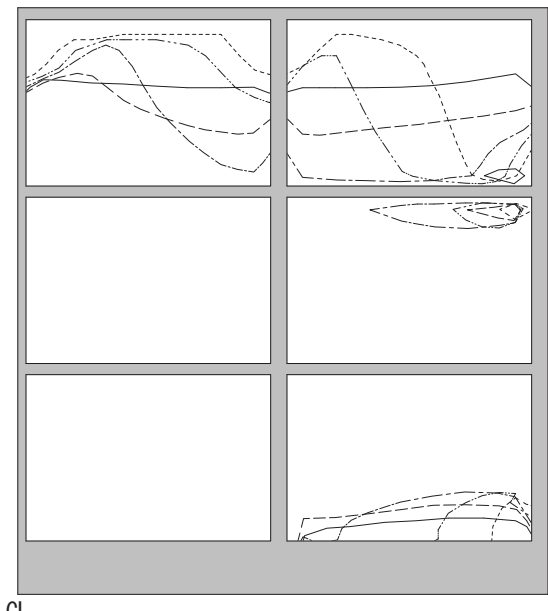

（f） 3F4S・剛性比2.0 


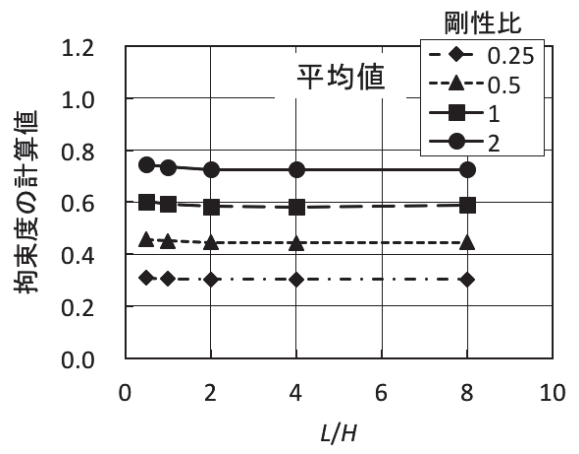

（a）剛性比の影響（3F4S）

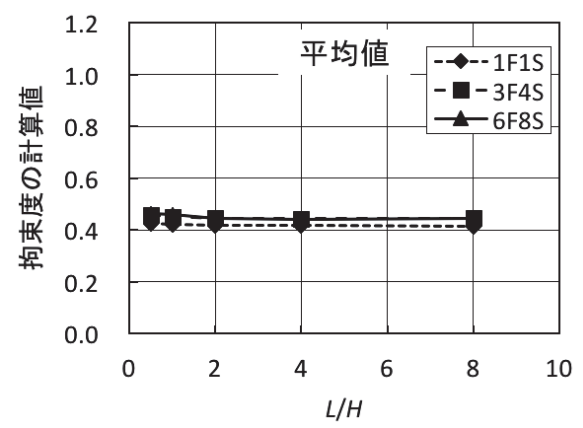

（b）層数・スパン数の影響（剛性比 0.5 )

図10 下端部の特異領域における拘束度の計算値
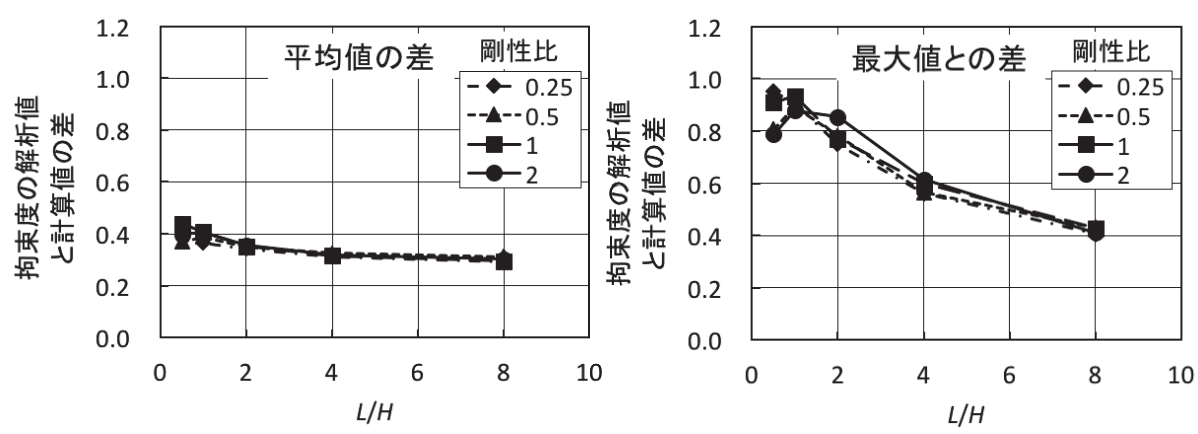

（a）剛性比の影響 (3F4S)
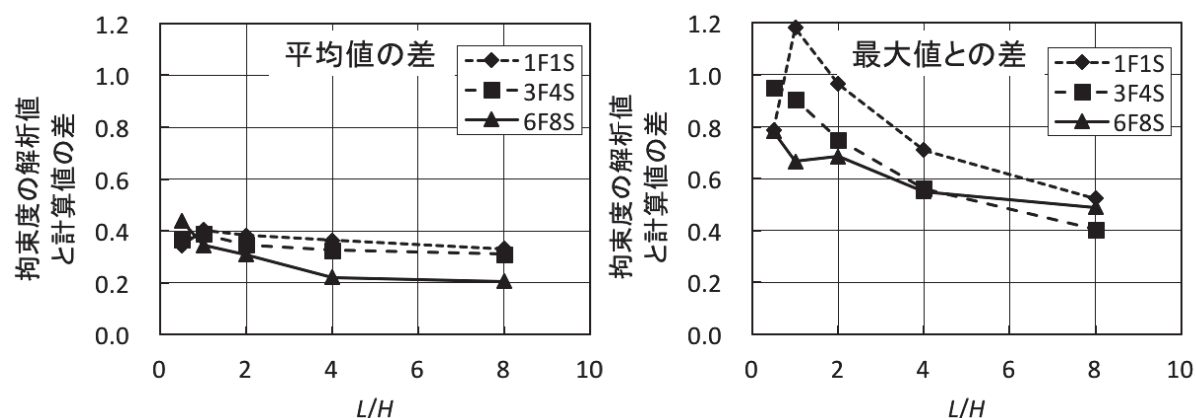

(b) 層数・スパン数の影響（剛性比0.5)

図11 下端部の特異領域における拘束度の解析値と計算値の差

ことがわかる。このことから、 $L / H か ゙$ 比較的大きくて、扁平な形状 の壁面の中央付近（すなわち、曲げ変形が卓越し、平面保持の仮定 が成立する領域）では、既報4)で既に報告したように、1軸モデルに よる拘束度の計算值と実際の拘束度がほぼ等しくなるといえる。

\section{6. 拘束度マップ}

\section{1 拘束度の解析值が計算值より大きい領域}

図9に、拘束度のFEMによる解析值（以下、単に解析值という）が1 軸モデルによる計算值（以下、単に計算值という）より大きい領域 を、その差の閾值を 0.2 としてマッピングした結果を示す。同図は、 $L / H$ の異なるケースを1つの図中に重㸚て表示寸るために、図5の場 合と同様に、縦横の比が $L / H=2$ と同じになるように壁面の形状を修 正して示してある。

この拘束度マップによると、せん断変形が卓越して平面保持の仮 定が成立しない壁面の下端部と上端部（図中における右端の下部お よび上部）に、拘束度の解析值が計算值より大きい領域（以下、特 異領域という）が存在する。また、特異領域に関して次のことがい える。

(1) $L / H$ が大きいほど、上下端部の特異領域の横幅の、壁面の横幅に 対する比率が小さくなり、また、縦幅が広くなる。

(2)層数・スパン数が同じ場合、剛性比が大きいと、上端部の特異領 域が縦横に拡大寸る。ただし、下端部の特異領域の位置や大きさ はほとんど変化しない。

(3) 層数・スパン数が多くなると、下端部の特異領域は梁・柱により 分断されるが、その領域全体の占める位置はほとんど変化しな い。

なお、この拘束度マップを利用した実務的な収縮ひび割れ制御対 策としては、次の方針が考えられる。すなわち、(1)建物の壁面全体 に対しては、1軸モデルにより拘束度を求めてひび割れ発生状況を予
測し、適切な対策を講じる。(2)れとは別に、拘束度の特異領域に 対しては、別途、局所的・追加的な対策を施す。

\section{2 下端部の特異領域}

(1) 拘束度の值

下端部の特異領域では、上端部の特異領域に比べて拘束度の值が 大きいので、本節では、この領域に着目してより詳細な検討を行っ た。

図10に、下端部の特異領域における拘束度の計算值を示す。また、 図11に、下端部の特異領域における拘束度の解析值と計算值の差を 示す。ここで、拘束度は、特異領域の範囲内においてもある程度の 幅をもって分布しているため、図10にはその平均值を示し、図11に は、平均值の差（解析值の平均值一計算值の平均值）および最大值 との差（解析値の最大値一計算值の平均値）の2種類の值を示してあ る。

図11(a)によると、L/Hが小さいほど（すなわち、縦長な形状であ るほど）、最大值との差は大きくなっているが、平均值の差はあま り変化していない。また、剛性比が変化しても平均值の差、最大值 との差のいずれもほとんど変化していない。このことから、下端部 の特異領域における拘束度の平均值は、1軸モデルによる計算值に、 ある一定值を足し合わせることにより推定できるといえる。また、 その值としては 0.4 程度を見込んでおけば概社問題ないものと考えら れる。なお、図11(b) からわかるように、解析值と計算值の差は、層 数・スパン数が増加するとやや小さくなる傾向となっている。

\section{(2) 拘束方向}

図12に、下端部の特異領域における拘束方向（最大主ひずみ方向） の角度の平均值および最大・最小值と $L / H$ の関係を示す。同図か ら、いずれのケースにおいても平均的に角度 $30 \sim 35^{\circ}$ の方向に拘束が 生じていることがわかる。また、このことから、例えば、下端部の 特異領域にひび割れ補強筋を配置してひび割れ幅を抑制するという 


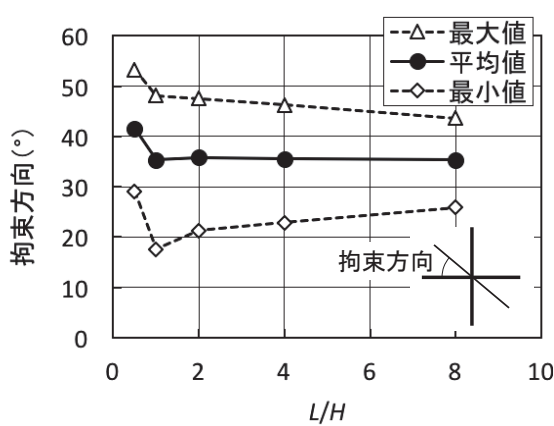

(a) 1 F $1 \mathrm{~S} \cdot$ 剛性比 0.5

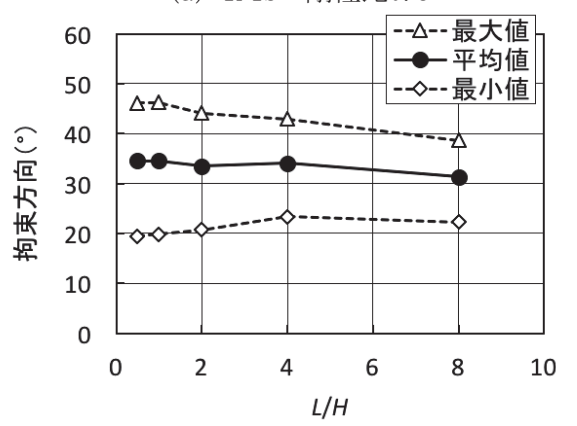

(d) $3 \mathrm{~F} 4 \mathrm{~S} \cdot$ 剛性比 0.25

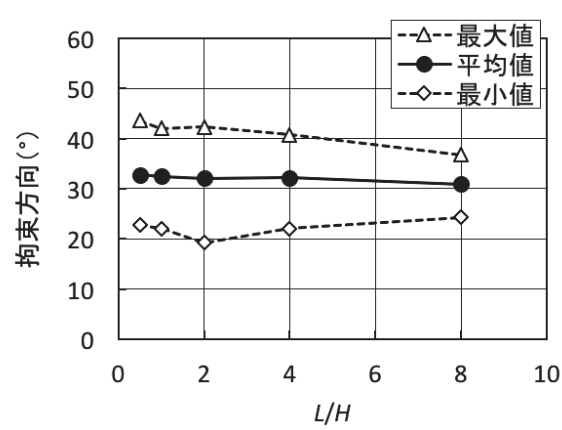

(b) $3 \mathrm{~F} 4 \mathrm{~S} \cdot$ 剛性比 0.5

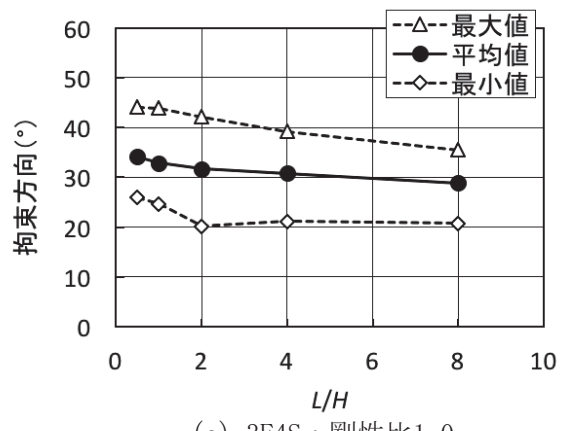

(e) $3 \mathrm{~F} 4 \mathrm{~S} \cdot$ 剛性比 1.0

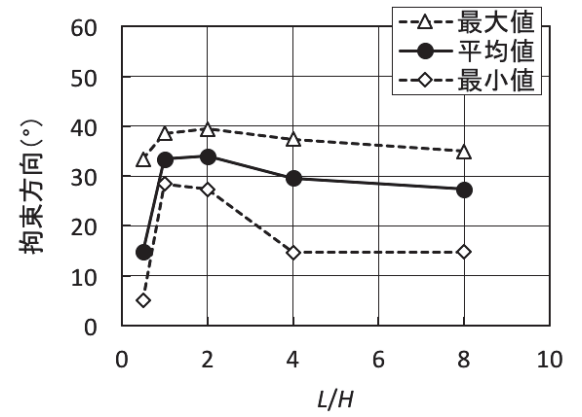

(c) $6 \mathrm{~F} 8 \mathrm{~S} \cdot$ 剛性比 0.5

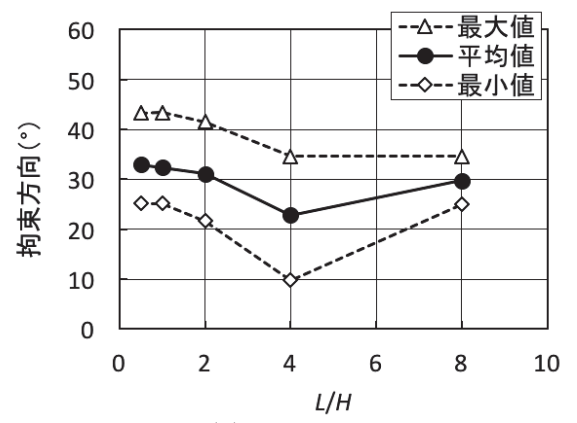

(f) $3 \mathrm{~F} 4 \mathrm{~S} \cdot$ 剛性比2.0

図12 下端部の特異領域における拘束方向

対策を講じる場合、どのような壁であっても、その配筋角度を 30 〜 $35^{\circ}$ 程度とすれば、ひび割れの制御効果が最大化されるといえる。

\section{7. まとめ}

本研究では、条件を様々に変化させたコンクリート壁面における 拘束度分布をFEM解析と 1 軸モデルにより計算し、それらの結果を整 理して、収縮ひび割れ制御設計資料とするための拘束度マップを作 成した。また、作成した拘束度マップに関して以下の知見を得た。

（1）壁面全体を1軸モデルに置き換える方法により計算した值より も拘束度が大きくなる領域（特異領域）は、壁面の下端部と上端部 に分布する。

（2）下端部の特異領域の位置や大きさは、剛性比（基礎の水平方向 の軸剛性/地上部分の梁の水平方向の軸剛性の合計）が変化してもほ とんど変化しない。また、この領域は、壁面の形状が扁平であるほ ど垂直方向に広くなる。さらに、層数・スパン数が増加すると、下 端部の特異領域は梁・柱により分断されるが、その領域全体の占め る位置はほとんど変化しない。

（3）下端部の特異領域における拘束度の平均値は、1軸モデルによ る計算值に対してある一定值（0.4程度）を足し合わせた值となる。 また、この領域における拘束方向は、どのような壁であっても平均 的に $30 \sim 35^{\circ}$ の角度となる。

\section{謝辞}

本研究の実施に際し、名城大学理工学部社会基盤デザイン工学科・ 石川靖晃教授に解析プログラムを提供して頂いた。ここに付記して 感謝の意を表します。

\section{参考文献}

1）中西正俊：コンクリートの収縮ひび割れ発生に関連してのFEMによるモデ ル架構の拘束率の推定, 日本建築学会大会学術講演梗概集, pp. 169-170, 1976. 10

2）鈴木計夫，大野義照，清水久博：コンクリートの乾燥収縮ひび割れ発生に 関するモデル架構の拘束率（有限要素法解析による推定），日本建築学会 近畿支部研究報告集, pp. 5-8, 1989. 5

3）尹重建, 岸本一蔵, 大野義照：RC造壁の乾燥収縮ひび割れ本数算定のため の拘束度評価，コンクリート工学年次論文集，Vol. 31，No. 1, pp. 685-690, 2009. 7

4）寺西浩司, 山田一徳：乾燥收縮するコンクリート壁部材の拘束度分布に関 寸る研究，日本建築学会構造系論文集，Vol. 75，No.653，pp. 1181-1188， 2010. 7

5）日本建築学会：鉄筋コンクリート造建築物の収縮ひび割れ制御設計・施工 指針（案）・同解説，2006.2

6）田辺忠顕：初期応力を考慮した RC構造物の非線形解析法とプログラム，技 報堂出版, 2004.3

7） 中崎大樹, 寺西浩司, 山田一徳, 今井一登: 壁部材の拘束度分布に関寸る 研究，その2. 実験およびFEM解析の結果，日本建築学会大会学術講演梗概 集, A-1, pp. 317-318, 2009.8

8）土木学会，コンクリート標準示方書［設計編］（2007年版），2008.3

9）日本コンクリート工学協会：マスコンクリートの温度応力研究委員会報告 書, 1985.11 


\title{
MAPPING OF RESTRAINING RATIO FOR CONCRETE WALLS \\ WITH DRYING SHRINKAGE
}

\author{
Kohji TERANISHI* and Yuichi NAKAMURA** \\ * Prof., Dept. of Architecture, Faculty of Science and Technology, Meijo Univ., Dr.Eng. \\ ** Building Division, Yahagi Construction Co., Ltd., M.Eng.
}

The free shrinkage deformation occurring in concrete members is generally restrained by members around one with different stiffness and shrinkage rate, and a restraining ratio which expresses degree of restraining has a major influence on state of shrinkage cracking. Therefore, in order to predict the shrinkage cracking, it is important to get the restraining ratio of concrete members in addition to free shrinkage strain of concrete.

With this background, in order to prepare eventually a design material for controlling shrinkage cracking with the organized distribution of restraining ratio, an experimental and analytical study to find out the regularity of distribution of restraining ratio in concrete walls was previously performed by authors. Additionally, it was noted that the restraining ratio in a wall with drying shrinkage should be reasonably considered by dividing it into the following two areas.

(1) Non edge area: the area whose restraining direction is horizontal and distribution of vertical direction of restraining ratio is linear because bending deformation is dominant and Bernoulli-Euler's hypothesis holds. The distribution of restraining ratio in this area can be calculated by replacing a concrete wall with a uniaxial model.

(2) Edge area: the area whose restraining direction is turbulent and distribution of vertical direction of restraining ratio is non-linear because shear deformation is dominant and Bernoulli-Euler's hypothesis does not hold.

This signifies that the distribution of restraining ratio in concrete walls can be potentially predicted by the following policy: (1) First, the distribution of restraining ratio in a concrete wall is calculated by the uniaxial model, (2) Next, the position of areas to which the value calculated at above (1) can be not applied (i.e. edge area) and the value of restraining ratio in those areas is obtained from the design material prepared previously, considering various conditions of concrete walls.

In this study, the map of distribution of restraining ratio in concrete walls, which is the design material in line with above policy, was created. In particular, the distribution of restraining ratio in concrete walls with various conditions was calculated by FEM analysis. Moreover, the areas to which the value calculated by the uniaxial model can be not applied (peculiar areas) were shown by organizing that result, and restraining ratio and restraining direction in those areas were shown.

The distribution of restraining ratio shown in the map has the following characteristics.

(1) The peculiar areas occur at the upper and lower parts of both ends of a wall.

(2) The position and largeness of peculiar area at lower part of both ends of a wall hardly changes depending on stiffness balance between members. Additionally, the area extends vertically as the shape of a wall is horizontally long. Furthermore, though the area is decoupled by columns and beams with increased number of layer and span, the position of that entire area hardly changes.

(3) The average restraining ratio at the peculiar area at lower part of both ends of a wall is obtained by adding a constant value (approximately 0.4) to the restraining ratio calculated by the uniaxial model, and the average restraining direction at the area is $30^{\circ}$ to $35^{\circ}$ in any wall. 